\title{
First mid-Neoproterozoic paleomagnetic results from the Tarim Basin (NW China) and their geodynamic implications
}

\author{
Yan Chena, $\underline{b}$, Bei Xuạ, Sheng Zhana and Yongan lic \\ a Key Laboratory of Orogenic Belts and Crustal Evolution, Ministry of \\ Education, Peking University, Beijing 100871, China \\ b ISTO, Département des Sciences de la Terre, Université d'Orléans, 45067, \\ Orléans, France \\ c Institute of Geology, BGMRED of Xinjiang, Urumqi 830000, China
}

\section{Abstract}

In order to improve the understanding of the configuration and breakup history of the Rodinia supercontinent, a paleomagnetic study has been carried out on the $807 \pm 12 \mathrm{Ma}$ Aksu dyke swarm (ADS) in Aksu area, northwestern Tarim Block (NW China). The magnetic mineralogical investigations show that the magnetic remanence is principally carried by automorphous titanium-poor magnetite. The measured samples from nine dykes present stable magnetic directions with both normal and reversed magnetic polarities. Because of the monoclinal bedding of overlying sedimentary rocks, no fold test can be provided. However, a positive reversal test is obtained. The magnetic site-mean direction in geographic coordinates is close to, but significantly different from, the present earth field (PEF). A tiltcorrected paleomagnetic pole, therefore, is computed: $19^{\circ} \mathrm{N}, 128^{\circ} \mathrm{E}, \mathrm{DP}=6^{\circ}$, $\mathrm{DM}=7^{\circ}$ with $N=9$. This new paleomagnetic observation reveals that the Tarim Block was located at an intermediate latitude of $43 \pm 6^{\circ} \mathrm{N}$. Integrating the geochronological studies of dyke swarms from Australia and the Aksu area and referring to the configuration of the Rodinia supercontinent proposed by Moores [Geology 19 (1991) 425] and Li and Powell [Earth Sci. Rev. 53 (2001) 237], the Tarim Block was placed north of Australia with the Aksu dykes being a possible northward continuation of lamprophyre dykes and kimberlite pipes in the northeast part of the Kimberley Craton, Western Australia.

Author Keywords: Rodinia; Dykes; Paleomagnetism; Proterozoic; Tarim; Aksu 


\section{Introduction}

The existence of the Rodinia supercontinent has been accepted well, though the history for its assembly, configuration and breakup is still debated. For example, Moores (1991), Dalziel (1991) and Hoffman (1991) suggested that the Southwest US-East Antarctica (SWEAT) connection might have started at $1.9 \mathrm{Ga}$, however, Li and Powell (2001), argued that this connection did not exist until Laurentia and East Gondwanaland were sutured at around $1 \mathrm{Ga}$. Concerning the configuration of this supercontinent, as distinguished from the SWEAT and AUWSUS models proposed by Moores (1991), Karlstrom et al. (1999) and Burrett and Berry (2000), respectively, based essentially on Grenvillian foldbelt distribution, Li et al. (1996) suggested an alternative hypothesis regarding the relative positions between the South China Block (SCB), the North China Block (NCB), Australia, Laurentia, Siberia, Tarim and Cimmerian blocks. Regarding the timing of breakup, compatibility of paleomagnetic data in the 1100-760 Ma interval and their disparity from 750 Ma between Gondwanaland and Laurentia has led paleomagnetists to propose this latter age as the end of the Rodinia supercontinent (e.g. Li, 2000 and Wingate and Giddings, 2000); the breakup might be initiated by a mantle plume upwelling evidenced by massive intrusion of mafic rocks (e.g. Park et al., 1995 and Wingate et al., 1998; Li et al., 1999; Li et al., 2003a and ㄴi et al., 2003b); According to some stratigraphic correlations, however, the Rodinia would rather appear to be broken up at around 550-560 Ma (Bard et al., 1989; Veevers et al., 1997). It is obvious that further geochronological constraints and paleomagnetic studies on precisely dated rocks may provide critical answers. The mid-Neoproterozoic mafic dyke swarm intruding into blueschist in the Aksu area of the northwestern Tarim Basin offers a good opportunity for such a study.

\section{Geological setting}

The Aksu area is located in the northwestern part of the Tarim Basin, NW China (Fig. 1a). With an excellent geologic exposure of about $15 \mathrm{~km} \times 40 \mathrm{~km}$, stratigraphic successions includes the Early Neoproterozoic Aksu Group, the late Neoproterozoic Sugetbrak and Chigebrak Formations, and the Lower Cambrian Yuertus Formation (Fig. $1 \mathrm{~b}$ and $\mathrm{c}$ ). The Aksu Group is mainly composed of psammitic, pelitic and mafic schists intercalated with quartzites, meta-ironstones and metacherts (BGMRXJ, 1982). This group is characterized by widespread occurrence of blueschist ( Liou et al., 1989; Liou et al., 1996 and Zhang et al., 1999). The late Neoproterozoic Sugetbrak Formation, unconformably overlying on the Aksu Group and unconformably overlain by the Lower Cambrian siliceous rocks, consists of clastic rocks in the lower part and of carbonates in the upper part ( Gao et al., 1985). Comparing to stratigraphic occurrences in South China where both Lower and Upper Sinian successions are observed, the early Sinian (about 820-750 Ma) appears to be 
absent between the Early Neoproterozoic Aksu Group and late Neoproterozoic Sugetbrak Formation (Fig. 1b and c; Gao et al., 1985).
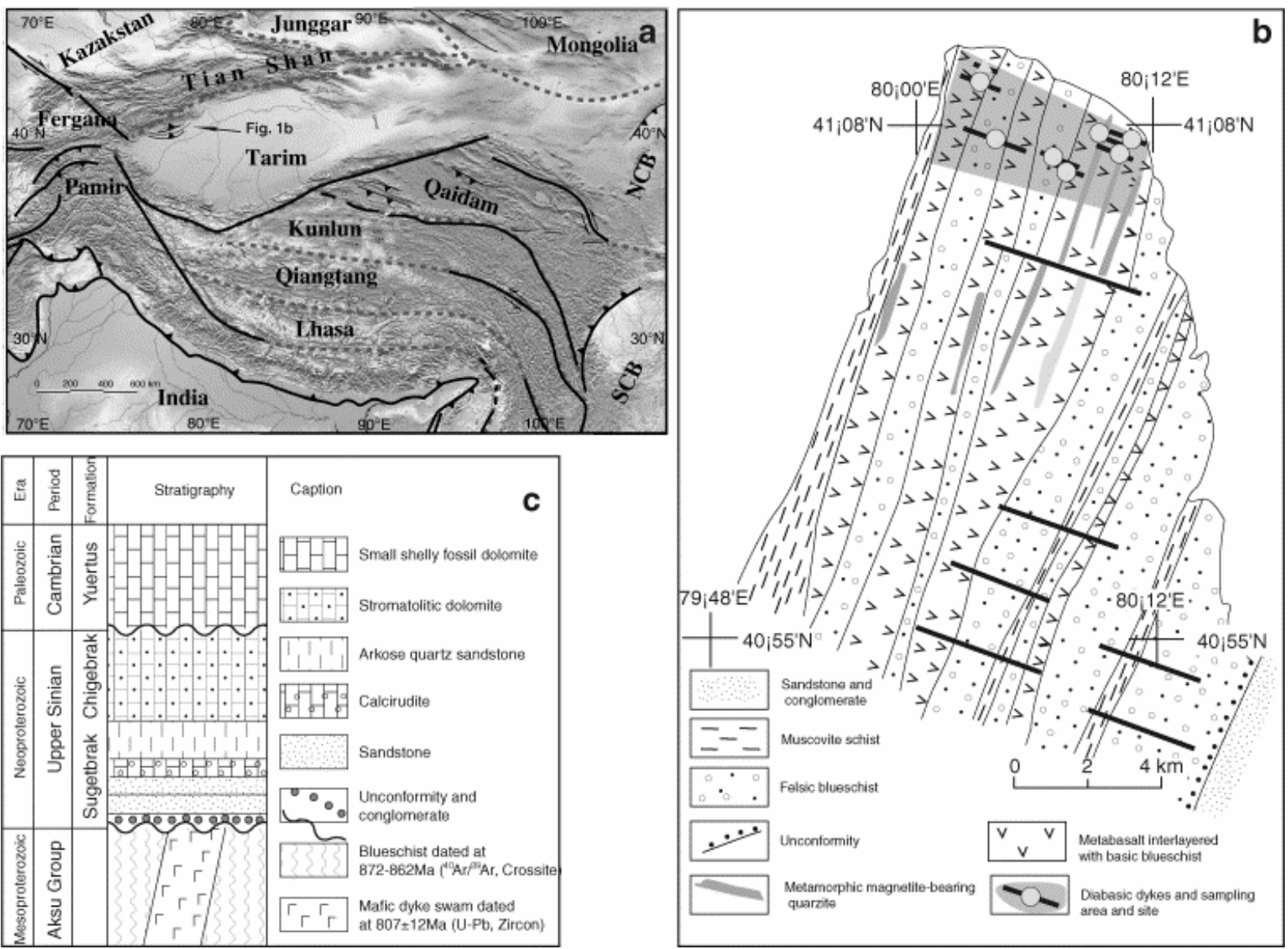

Fig. 1. (a) Topographic and simplified tectonic map of the Tarim Basin and its surrounding areas. Solid and dashed lines stand for active faults and ancient sutures, respectively. SCB and NCB correspond to North and South China blocks, respectively. (b) Simplified geologic sketch map of Aksu area (after Liou et al., 1989 and Zhang et al., 1999). (c) Stratigraphic column of the Asku area (after Gao et al., 1985 and Zhang et al., 1999). The thickness is not to scale. Isotopic ages are described in detail in the text.

A series of parallel mafic dykes have intruded into the Aksu Group and extend for 5-10 km (Fig. 1b). The dykes are older than late Neoproterozic because they only penetrate the Aksu Group and are unconformably overlain by basal conglomerates and coarse sandstone of the late Neoproterozoic Sugetblak Formation in which pebbles of dykes are found. Two distinct deformation episodes have been recognized in the Aksu Group ( Liou et al., 1989). The first one results in the predominant foliations, lineations, and inclined recumbent isoclinal folding of primary layering, which is considered to be contemporaneous with blueschist-facies metamorphism. The second one formed map-scale northeast-southwest-oriented broad and open folding, including a series of synforms and antiforms. 
The orientations of mapped dykes, perpendicular to the fold axis of the synforms and antiforms, are relatively coherent varying from $310^{\circ}$ to $330^{\circ}$ in strike and from $65^{\circ}$ to $75^{\circ}$ in dip to the SW. The width of most dykes ranges from 2 to $10 \mathrm{~m}$, with some exceptions of more than $30 \mathrm{~m}$ wide (Sites 8 and 9). The general bedding of the overlying coarse sedimentary strata dips $48^{\circ}$ toward $136^{\circ}$. It is worth to note that none of the tight folding and metamorphism observed in the Aksu Group has been observed in these mafic dykes or the overlying late Neoproterozoic rocks in the Aksu area. The dikes consist mainly of Ti-augite, Ti-bearing brown hornblende, Ti-biotite, sericitized plagioclase and chloritized olivine pseudomorphs (Liou et al., 1989). Geochemical analyses of major and trace elements from seven measured samples indicate that the dikes, with $\mathrm{SiO}_{2}$ contents of $48.44-51.94 \%$, are characterized by high alkali, $\mathrm{TiO}_{2}$ and $\mathrm{P}_{2} \mathrm{O}_{5}$ contents and possess geochemical characteristics of within-plate basalts (Liou et al., 1996).

Several geochronological studies were carried out on the Aksu blueschist. Three peak metamorphic ages were obtained: $K-A r$ isochron ages of $718 \pm$ $22 \mathrm{Ma}$ and $\mathrm{Rb}-\mathrm{Sr}$ age of $698 \pm 26 \mathrm{Ma}$ from phengitic mica and whole-rock, respectively (Nakajima et al., 1990), and ${ }^{40} \mathrm{Ar} / 39 \mathrm{Ar}$ age of $754 \mathrm{Ma}$ from sodic amphibole (Liou et al., 1996). Two severe weaknesses may arise concerning these ages: (1) in the general case, the closure temperature of the Rb-Sr system is higher than the K-Ar system, the Rb-Sr age should, therefore, be older than the K-Ar age for the same sample, yet, Nakajima et al. (1990) found an inverted progression; (2) the analytic quality of these ages is questionable. Relatively larger errors are presented in Nakajima et al. (1990; 22-26 Mal, and no statistical precision is reported by Liou et al. (1996). It is difficult to assess the peak metamorphic age of the Aksu blueschist by these available data. So a parallel thermo-geochronologic study was carried out on Aksu dykes (Zhang, L.F., personal communication). The preliminary results show two ${ }^{40} \mathrm{Ar} /{ }^{39} \mathrm{Ar}$ thermochronological isotopic data, $872 \pm 2 \mathrm{Ma}$ from crossite and $862 \pm 1 \mathrm{Ma}$ from glaucophane of the Aksu blueschist, indicating a peak metamorphism stage during 872-862 Ma. A high-resolution microprobe (SHRIMP) U-Pb age of $807 \pm 12 \mathrm{Ma}$ from zircons has also been obtained from mafic dykes in this study area, suggesting an intrusive event of the dyke swarm following the peak metamorphism of the Aksu blueschist (Zhang, L.F., personal communication). These new ${ }^{40} \mathrm{Ar} /{ }^{39} \mathrm{Ar}$ thermochronological and SHRIMP U-Pb chronological data are consistent with the field geological relationship between the Aksu blueschist and the dyke swarm. Therefore, we consider $807 \pm 12 \mathrm{Ma}$ as the intrusive age of the Aksu mafic dyke swarm from which paleomagnetic sampling was carried out.

In the northwestern Aksu accessible area, nine dykes were paleomagnetically sampled. Depending on dyke widths, 6-14 cores were drilled from each site by a gasoline drill (Fig. 1b). Core azimuths were orientated by both magnetic and solar compasses, when possible. The difference between the two measurements averaged $3.4 \pm 2.3^{\circ}$, and this mean value is used for the orientation corrections for those measured only by magnetic compass. 


\section{Paleomagnetic analyses}

\subsection{Laboratory measurement and directional analytic techniques}

In the laboratory, cores are prepared into standard specimens with $2.5 \mathrm{~cm}$ in diameter and $2.2 \mathrm{~cm}$ in length. Several methods were applied to magnetic mineralogical investigations: thermal magnetic experiment (KLY-3S kappabridge susceptibility-meter coupled with a CS3 furnace), the acquisition of isothermal remanent magnetization (IRM; IM30 pulse magnetizer) and the measurements of anisotropy of magnetic susceptibility (AMS; KLY3 kappabridge susceptibility-meter) in Laboratoire du Magnétisme des Roches d'Orléans (LMRO); magnetic hysteretic curves in Laboratoire du Paléomagnétisme of Institut de Physique du Globe de Paris (IPGP) at St Maur; Scanning Electronic Microscopy in Key Laboratory of Orogenic Belts and Crustal Evolution, Ministry of Education, Beijing University. Both thermal and alternating magnetic field (AF) demagnetizations were applied to clean the magnetic remanence in LMRO, and AF demagnetizations in IPGP, through a laboratory built furnace and LDA-3 demagnetizer, respectively. The magnetic remanence was measured by JR5 spinner magnetometer. The magnetic remanent directions were isolated by principal component analysis (Kirschvink, 1980) and the mean directions are computed by Fisher spherical statistics (1953) using paleomagnetic software packages offered by Cogné (2003) and R. Enkin.

\subsection{Magnetic mineralogical analyses}

Isothermal magnetization measurements show an abrupt increase of IRM Up to about $200 \mathrm{mT}$ without the total saturation up to about $1 \mathrm{~T}$, indicating predominantly soft-coercivity magnetic minerals in samples (Fig. $2 a$ and b). Thermal magnetic experiments reveal a sharp drop of magnetic susceptibility at about $560-580^{\circ} \mathrm{C}$ with some evidence for Hopkinson peak, indicating the existence of (pseudo) single-domain titanium-poor magnetite (Fig. $2 \mathrm{c}$ and d; Dunlop and Ozdemir, 1997). Slight drops at about $300-350^{\circ} \mathrm{C}$ and after $600^{\circ} \mathrm{C}$ show the presence of possible pyrrhotite and hematite in treated samples, respectively (Fig. $2 \mathrm{c}$ and d). The magnetic hysteretic curves confirm these interpretations. The induced magnetic moment is saturated at about 200$300 \mathrm{mT}$ with saturation moments ranging from about 1.5-2.5 Am²/ $\mathrm{kg}$ (Fig. 2e and f). Coercivity force ( $\mathrm{Hc}$ ) varies from 15 to $45 \mathrm{mT}$. The ratios of Js/Jrs and $\mathrm{Hc} / \mathrm{Hrc}$ vary from 0.19 to 0.39 and 1.67 to 1.88 , respectively. These values show typical characteristics of titano-magnetite (Dunlop, 1986). Fig. $2 \mathrm{~g}$ and $\mathrm{h}$ present some detail information on size, shape and composition of opaque magnetic minerals by scanning electronic microscopy. Titano-magnetites are widely identified with angular shape and variable crystal sizes from tens of $\mu \mathrm{m}$ to $\mathrm{mm}$. Bar-shaped structure of ilmenite lamella exsolutions has been observed in titano-magnetite crystals ( Fig. 2h). This is typical structure for basaltic rocks resulting from the exsolution of ilmenite during magmatic cooling between 550 and $515^{\circ} \mathrm{C}$ (Spencer and Lindsley, 1981). No significant 
later chemical or mechanical destabilization is apparent. The above observations indicate that the magnetic remanence in this paleomagnetic collection is mainly carried by automorphous titanium-poor magnetite.
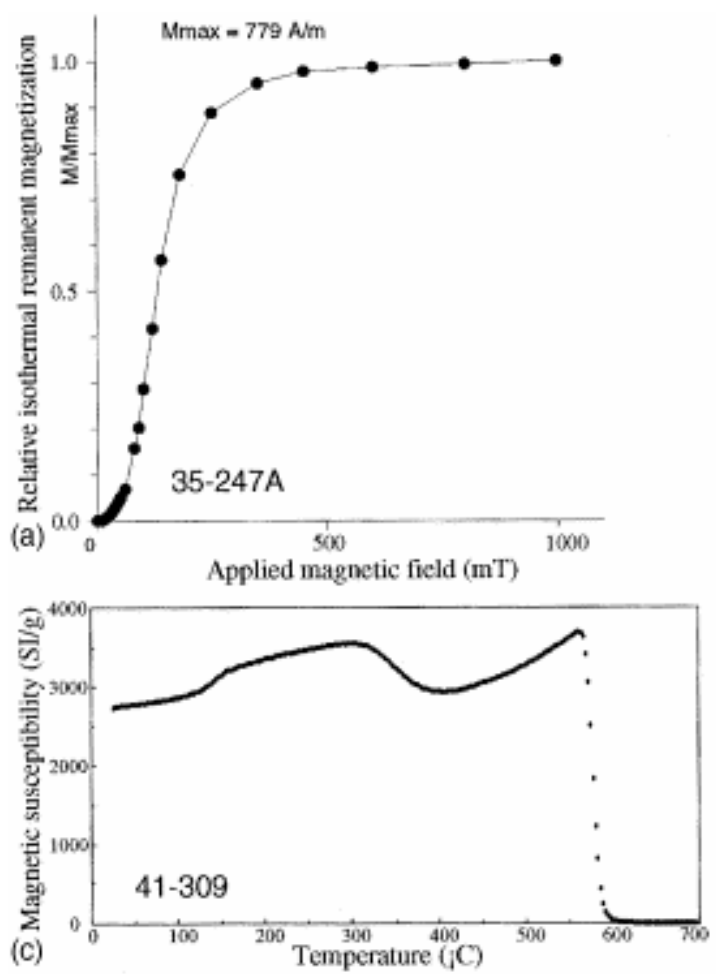

(C)

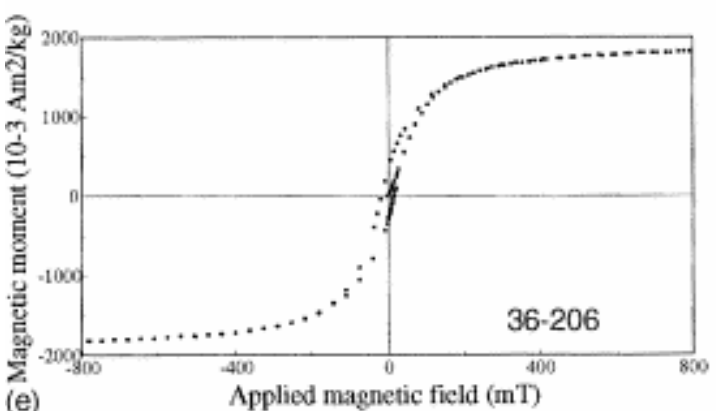

(e)

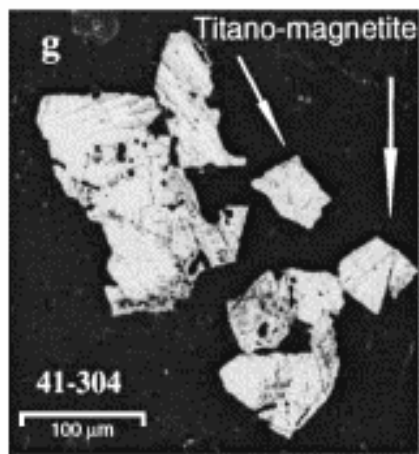

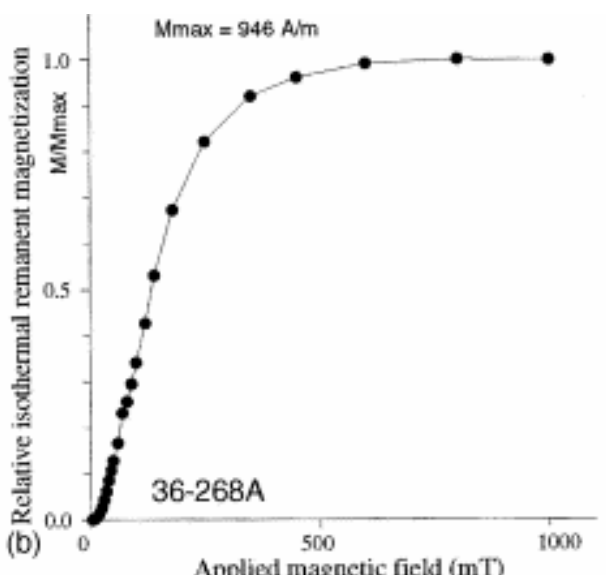
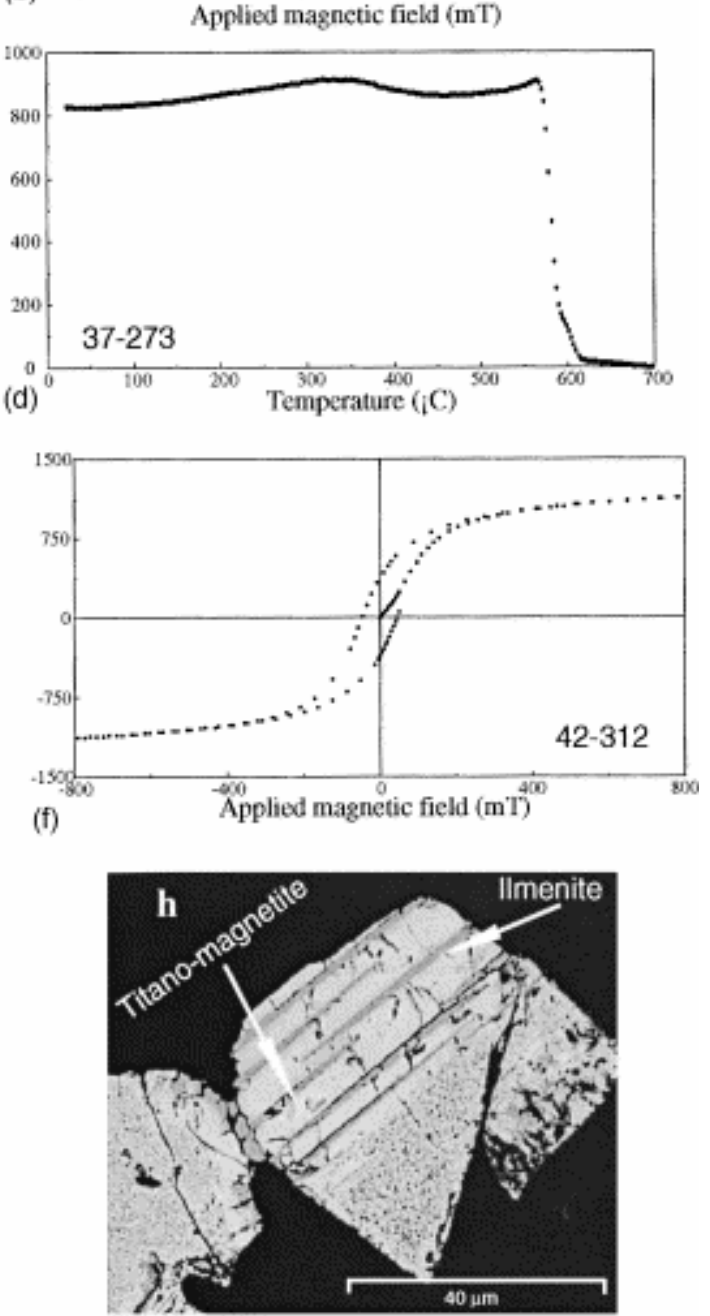

Fig. 2. Magnetic mineralogic analyses. (a) and (b) concern IRM measurements; (c) and (d) result from thermomagnetic experiments; (e) and (f) are representative magnetic hysterestic curves; (g) and (h) are from scanning electronic microscopy. 


\subsection{Magnetic direction analyses}

A pilot study has been carried out on both thermal and AF demagnetizations. The natural remanent magnetization (NRM) varies from 0.07 to $2.03 \mathrm{~A} / \mathrm{m}$ with an average of $0.71 \pm 0.66 \mathrm{~A} / \mathrm{m}$. About 15 steps have been applied to progressive magnetic remanence cleaning with intervals varying from 20 to $150^{\circ} \mathrm{C}$ for thermal demagnetization (Fig. $3 \mathrm{c}$ and e) and 1 to $20 \mathrm{mT}$ for AF (Fig. $\underline{3 a, b}$ and $d)$. Because both techniques show the similar results and AF seems more efficient, this latter has been used as the principal magnetic remanence cleaning technique though the most specimens have been heated to $150^{\circ} \mathrm{C}$ after the first measurement of NRM. Most measured specimens show stable mono-component behavior (Fig. 3a, b and e). Less than $30 \%$ specimens show multiple components ( Fig. $3 \mathrm{c}$ and d) and reversed polarity ( Fig. 3c-e). Table 1 lists all directional analysis results. Dual-polarity has been observed in Sites 38 and 39, sampled from dikes more than $30 \mathrm{~m}$ in width. The site-mean direction in geographic coordinates is: $D_{g}=349.3^{\circ}, I=61.8^{\circ}, k=130.7, a_{95}=4.5^{\circ}$ with $N=$ 9. This direction is close to both the present earth field (PEF; $D=3.8^{\circ}, 1=60.5^{\circ}$; Fig. 4a) or geomagnetic dipolar field $\left(I=60.2^{\circ}\right)$, but significantly different from these with angular differences of $4.1 \pm 3.6^{\circ}$ and $5.4 \pm 3.6^{\circ}$, respectively. Because the dikes are overlain by detrital rocks and the latter are folded, the magnetic directions of these dikes are therefore corrected according to the folding. The mean-site direction in stratigraphic coordinates is: $D_{s}=103.4^{\circ}, I_{s}=$ $62.3^{\circ}$ (Fig. 4b). A reversal test has been attempted though only a few reversed specimens are observed. A positive test is revealed with classification B ( McFadden and McElhinny, 1990). 

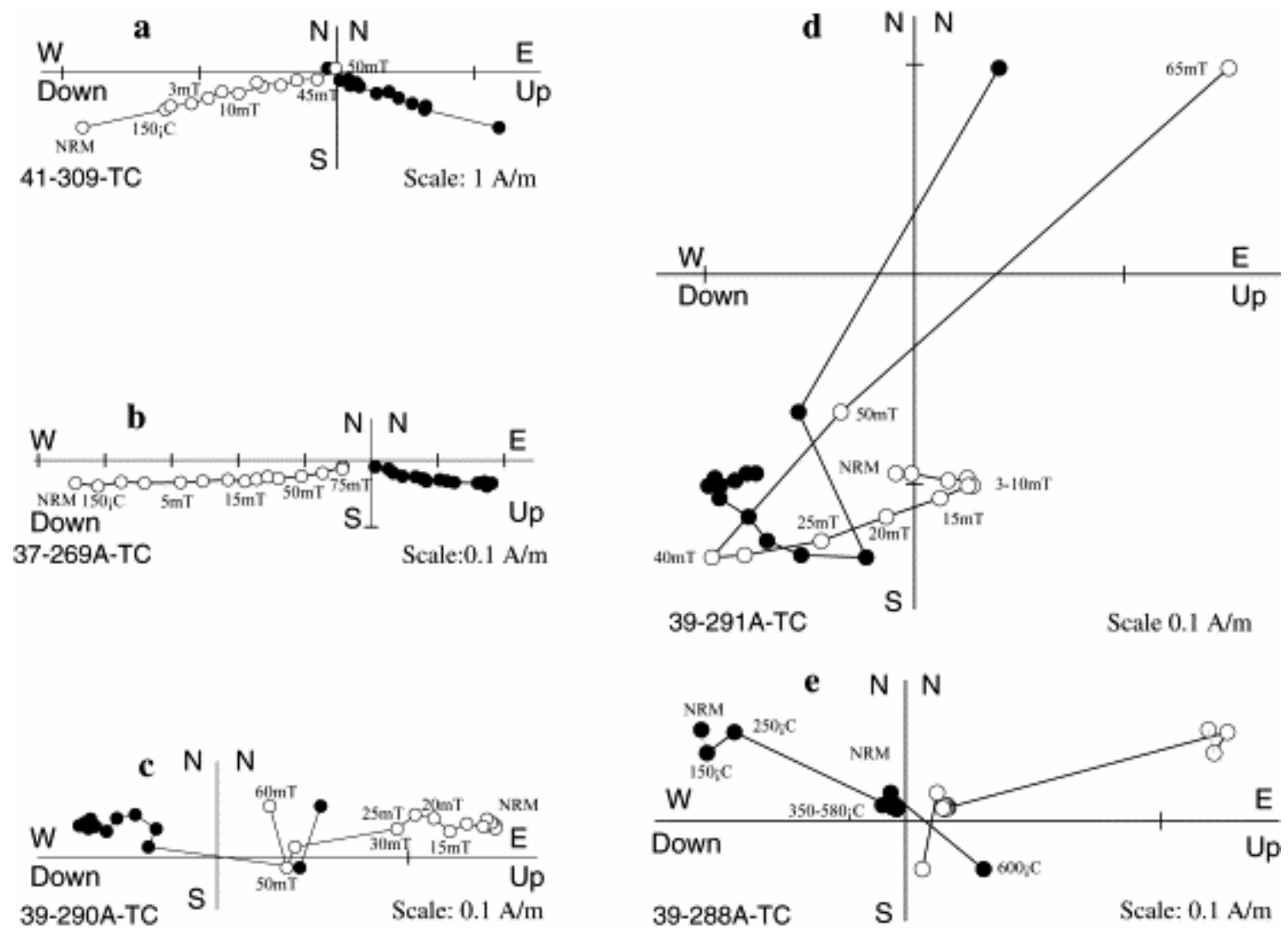

Fig. 3. Orthogonal projection in tilt-corrected coordinates of progressive demagnetization for representative samples (Zijderveld, 1967). Black (whites) dots present horizontal (vertical) plans.

$n / N$, number of samples used to calculate mean direction/number of demagnetized samples; $D_{g}, I_{g}, D_{s}, I_{s}, k$ and $a_{95}$, declination and inclination in geographic and stratigraphic coordinates with statistic precision and the radius that mean direction lies within $95 \%$ confidence.

\begin{tabular}{|c|c|c|c|c|c|c|c|c|}
\hline Site & $n N$ & Polarity & $D_{\mathrm{B}}$ & $f_{z}$ & $D_{1}$ & $h_{s}$ & $k$ & $\alpha_{35}$ \\
\hline 35 & $11 / 11$ & $\mathrm{~N}$ & 352.0 & 39.5 & 97.7 & 62.1 & 69.8 & 5.5 \\
\hline 36 & 4,4 & $\mathrm{~N}$ & 338.4 & 59.3 & 106.0 & 68.1 & 35.3 & 15.7 \\
\hline 37 & $7 / 7$ & $\mathrm{~N}$ & 351.1 & 58.1 & 95.2 & 63.2 & 10.1 & 19.9 \\
\hline 38 & $5 / 5$ & $\mathrm{~N}$ & 351.7 & 57.5 & 93.8 & 63.1 & 41.3 & 12.0 \\
\hline 38 & $2 / 3$ & $\mathbb{R}$ & 162.9 & -74.6 & 304.7 & -55.3 & - & - \\
\hline 38 & $7 / 8$ & $\mathbb{N}+\mathbb{R}$ & 344.7 & 61.0 & 104.6 & 64.6 & 28.7 & 11.5 \\
\hline 39 & $7 / 7$ & $\mathrm{~N}$ & 340.3 & 57.3 & 100.2 & 68.6 & 38.4 & 9.9 \\
\hline 39 & $4: 4$ & $\mathbb{R}$ & 167.6 & -66.0 & 291.6 & -60.5 & 4120 & 4.5 \\
\hline 39 & $11 / 11$ & $\mathbb{N}+\mathbb{R}$ & 342.5 & 60.5 & 105.2 & 65.7 & 50.6 & 6.5 \\
\hline 40 & $4 / 5$ & $\mathrm{~N}$ & 12.2 & 53.0 & 83.0 & 51.9 & 144.7 & 7.7 \\
\hline 41 & $5 / 5$ & $\mathrm{~N}$ & 350.4 & 66.8 & 111.4 & 59.1 & 79.6 & 8.6 \\
\hline 42 & $3 / 4$ & $\mathrm{~N}$ & 341.7 & 68.3 & 118.1 & 60.4 & 53.7 & 17.0 \\
\hline 43 & $7 / 7$ & $\mathrm{~N}$ & 343.2 & 66.1 & 114.1 & 61.8 & 41.2 & 9.5 \\
\hline Average & 9 & $\mathbb{N}+\mathbb{R}$ & 349.3 & 61.8 & 103.4 & 62.3 & 130.7 & 4.5 \\
\hline
\end{tabular}

Table 1. Summarized paleomagnetic results from the Aksu dyke swarm 


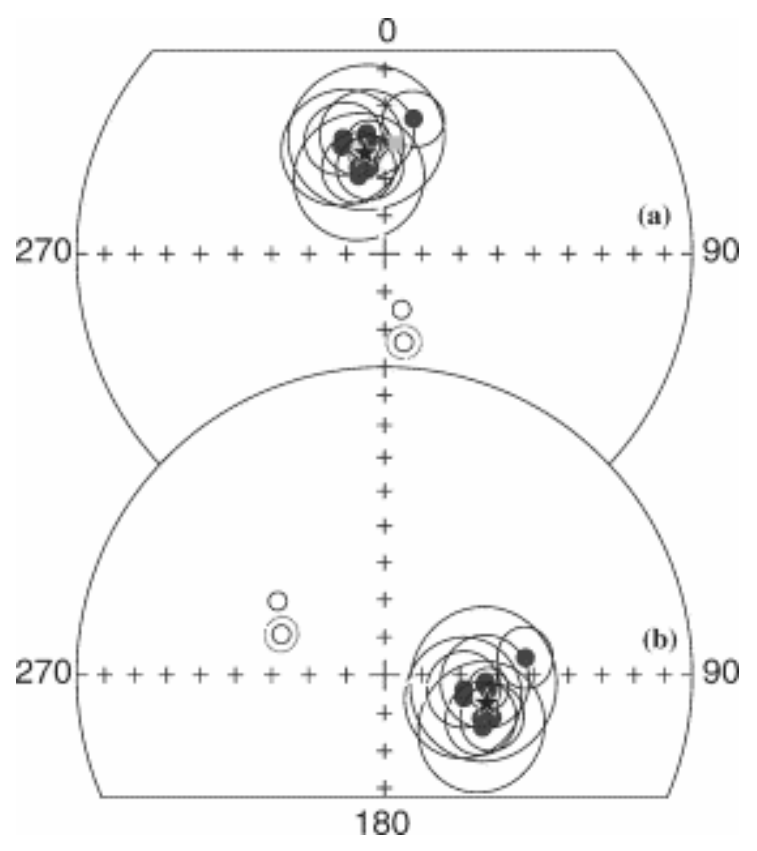

Fig. 4. Equal-area projection of mean-site directions in geographic (a) and stratigraphic coordinates. Stars present the average of means and the square stands for the present earth field.

\section{Disc ussion}

\subsection{Reliability of paleomagnetic data}

According to magnetic mineralogical investigations, automorphous titaniumpoor magnetite is the major remanence carrier in measured samples. Because deformation occurred in this area since the late Paleozoic, anisotropy of magnetic susceptibility measurements have been systematically carried out on specimens. Fig. 5 shows a relatively weak anisotropy degree $\left(P^{\prime}\right)$ with an average of $1.02 \pm 0.02$, implying that the dykes have not experienced significant deformation since their intrusion. Stable magnetic components and both normal and reversal polarities, as well as distinguishable site-mean direction in geographic coordinates from the PEF, indicate that the magnetic remanence is probably primary. Before the computation of paleomagnetic pole using the isolated magnetic directions, the bedding corrections of these dykes are worth a discussion. Supposing that these dykes are intruded in the same geodynamic context with relatively consistent geometry (orientation and dip), if these dykes had experienced differential folding along their geological history, their geometry should have become variable. However, the dykes sampled in this study present relatively coherent strike directions $\left(310-330^{\circ}\right)$ and dip angles $\left(65-75^{\circ}\right)$. Therefore, we assume that these dykes have experienced a uniform fold deformation. Based on the stratum geometry of overlying coarse sedimentary bedding that we have observed in the field, the dykes restore to within $\sim 10^{\circ}$ of vertical. The 
same bedding corrections have been made on the magnetic directions (Table 1) and the paleomagnetic pole is, therefore, calculated at $19^{\circ} \mathrm{N}, 128^{\circ} \mathrm{E}$, $\mathrm{DP}=6^{\circ}, \mathrm{DM}=7^{\circ}$ with a paleolatitude of $43 \pm 6^{\circ} \mathrm{N}$.

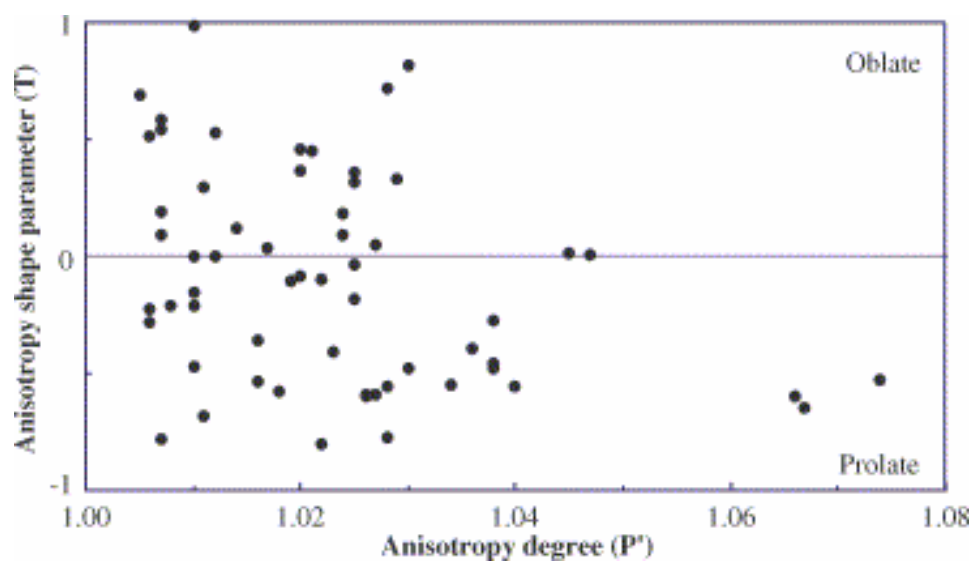

Fig. 5. Plot of anisotropy degree $\left(P^{\prime}\right)$ vs. anisotropy shape $(T)$ of magnetic susceptibility. $P^{\prime}=\exp \left\{2\left[\left(\ln K_{1}-\operatorname{lin} K_{m}\right)^{2+}\left(\ln K_{2}-\operatorname{lin} K_{m}\right)^{2+}\left(\operatorname{lin} K_{3}-\ln K_{m}\right)^{2}\right]^{1 / 2}\right\}$, and $T=\left[2 \ln \left(K_{2} / K_{3}\right) / \ln \left(K_{1} / K_{3}\right)\right]-1$ , where $K_{1}, K_{2}$ and $K_{3}$ are principal axes of the magnetic fabrics and $K_{m}$ is their average.

\subsection{Connection of between the Tarim Block and Australia and tectonic signific ance of the ADS}

"West" Rodinia is composed of Australia, India, East Antarctica, South China, Tarim Blocks and several other small ones (e.g. Fig. 1 of Powell and Pisarevsky, 2002). The configuration of this supercontinent is not well constrained because of the dearth in paleomagnetic and geochronologic data. In contrast to the SWEAT and AUWSUS models proposed by Moores (1991) and Karlstrom et al. (1999), respectively, Li et al., 1995 and Li et al., 1996 and Li and Powell (2001) evoked an alternative hypothesis with the following major differences: 1. South China lies between Australia and Laurentia-Siberia; 2. the Tarim Block is adjacent to northwestern Australia (see Fig. 2 of Li and Powell, 2001). This last hypothesis places Australia at about $35-40^{\circ} \mathrm{N}$ in latitude for the 1000 to $760 \mathrm{Ma}$ interval and the Tarim Block just to its north without any paleomagnetic control. The paleomagnetic results from the present study constrains better the paleogeographic position of the Tarim Block: $43 \pm 6^{\circ} \mathrm{N}$ in latitude with about $100^{\circ}$ clockwise rotation with respect to present orientation (Fig. 6). 


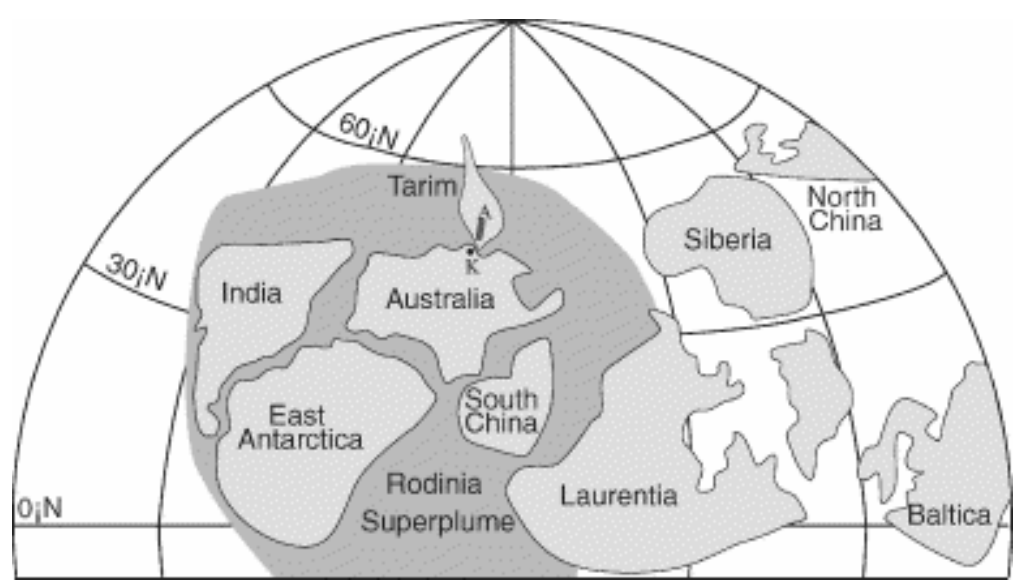

Fig. 6. Possible mid-Neoproterozoic position of the Tarim Basin with respect to the Rodinia supercontinent proposed by Li and Powell (2001) for the 1000-760 Ma interval. K stands for the Kimberley region.

According to dyke age determination and space distribution in Australia, a possible connection between the Tarim Block and Australia is proposed in Fig. 6. The Tarim Block is laid in the vicinity of Kimberley region (shown as $\mathrm{K}$ in Fig. 6), where northeastward trending lamprophyre dykes and kimberlite pipes are exposed in the northeast of the Kimberley Craton (Atkison et al., 1984). This trend is similar to that of the Aksu dykes after about $100^{\circ}$ counterclockwise rotation of the Tarim Block according to this study. The ages of 798-811 Ma and $802 \pm 14 \mathrm{Ma}$ from the Kimberley rocks (Pidgeon et al., 1989; Li et al., 2003a and Li et al., 2003b) are equally consistent with that from Aksu dykes (807 \pm $12 \mathrm{Ma}$ ). These observations may imply that these rocks could be related to the same magmatism event. In addition to magmatism, the Neoproterozoic Marinoan tillites and overlying sedimentary successions in Kimberley Proterozoic Basin (Li et al., 1996; Plumb, 1996; Corkeron et al., 1996 and Grey and Corkeron, 1998) are comparable to those in the Tarim Block ( Gao and Zhu, 1984; Gao et al., 1985 and Brookfield, 1994), providing further evidence for the Kimberley-Tarim connection ( Li et al., 1996; Fig. 6).

The hypothesis of Li and Powell (2001) for the Rodinia configuration is essentially developed from the discovery of co-genetic mid-Neoproterozoic mafic rocks in both South China and Australia. Thought to be of a mantle plume origin, mafic dykes and sills found in South China share an identical SHRIMP zircon age of $827 \pm 7$ Ma with those of Gairdner Dyke Swarm (GDS) and Little Broken Hill gabbro in southeastern Australia (827 $\pm 6 \mathrm{Ma}$; Zhao and McCulloch, 1993; Zhao et al., 1994; Gibson et al., 1996; Gibson et al., 1997; Wingate et al., 1998 and Li et al., 1999). Intrusion of these mafic rocks was accompanied by widespread granite emplacement. Later, studies on geochemistry and geochronology of granitoid and volcanic rocks from South China suggest that these rocks have resulted from crustal melting and developed in continental rifts and continental flood basalt provinces related to a mantle plume at ca. $825 \mathrm{Ma}$ ( Li et al., 1999; Li et al., 2003a and Li et al., 2003b; Ling et al., 2003). Consequently, South China is placed between 
Australia-East Antarctica and Laurentia in Rodinia supercontinent ( Fig. 6) and above the center of a mantle plume ( Li et al., 1995 and Li et al., 1996). The orientation, distribution and geochemical characteristics of the GDS are consistent with emplacement above a mantle plume ( Wingate et al., 1998). The ADS rocks are lithologically similar to those from South China volcanic rocks and GDS, but significantly younger by about $20 \mathrm{Ma}$ in age. Another important difference is that the ADS shows northerly trends after about $100^{\circ}$ clockwise rotation with respect to its present orientation, which is perpendicular to the northwest trending of the GDS. These may indicate that the ADS may not be correlated with them.

\section{Conclusions}

The first paleomagnetic study from SHRIMP dated mid-Neoproterozoic intrusive dykes in the Aksu area (NW Tarim) shows reliable magnetic remanent signatures: automorphous titanium-poor magnetite as principal magnetic remanence carrier, stable magnetic components, both normal and reversed polarities, no evidence for metamorphism nor significant deformation of sampled rocks; therefore the magnetization can be considered as primary. The magnetic direction isolated from stable component suggests an intermediate paleolatitudinal position of $43 \pm 6^{\circ} \mathrm{N}$ for the Tarim Block at the late mid-Neoproterozoic time with about $100^{\circ}$ rotation with respect to its present position. Referring to the configuration of Rodinia supercontinent proposed by Moores (1991) and Li and Powell (2001), the Tarim Block is placed north of Australia with the Aksu dykes being the northward continuity of lamprophyre dykes and kimberlite pipes in northeast Kimberley Craton, Western Australia.

\section{Acknowledgements}

This research is financed by Chinese National Science Foundation (project No: 40032010). We thank Drs. Zhang Lifei, Song Shuguang and Bruno Marchand for their assistance, providing their preliminary results as well as discussion. We gratefully acknowledge the constructive reviews provided by Drs. Z.X. Li and D.A.D Evans. This is a contribution of "Key Laboratory of Orogenic Belts and Crustal Evolution, Ministry of Education, Peking University, China".

\section{References}

Atkison, W.J., Hughes, F.E., Sith, C.B., 1984. A review of the kimberlitic rocks of Western Australia. In: Kornprobst, J. (Ed), Kimberlites I: Kimberlites and Related Rocks. Amsterdam, pp. 195-224.

BGMRXJ, 1982. Region Geology of Xinjiang Uygur Autonomous Region. Beijing Publishing House, p. 841 (in Chinese with English abstract). 
Brookfield, M.E., 1994. Problems in applying preservation facies and sequence models to Sinian (Neoproterozoic) glacial sequences in Australia and Asia. Precambrian Res. 70, pp. 143-147.

Burrett, C. and Berry, R., 2000. Proterozoic Australia-Western United States (AUSWUS) fit between Laurentia and Australia. Geology 28, pp. 103-106.

Cogné, J.-P., 2003. A Macintosh ${ }^{\mathrm{TM}}$ application for treating paleomagnetic data and making plate reconstructions. Geochem. Geophys. Geosyst. 4 (1), 10.1029/2001GC000227.

Corkeron, M., Grey, K., Li, Z.X., Powell, C.M., 1996. Neoproterozoic glacial episodes in the Kimerley region, northwestern Australia. Abstr. Geol. Soc. Aust. $41,97$.

Dalziel, I., 1991. Pacific margin of Laurentia and East Antarctica-Australia as a conjugate rift pair: evidence and implications for an Eocambrian supercontinent. Geology 19, pp. 598-601.

Dunlop, D., Ozdemir, O., 1997. Rock Magnetism. Cambridge University Press, p. 576.

Dunlop, D.J., 1986. The rock magnetism of fine particles. Phys. Earth Planet Int. 13, pp. $260-267$.

Fisher, R., 1953. Dispersion on a sphere. Proc. R. Soc. London, Ser. A 217, pp. 295-305.

Gao, Z.J., Wang, W.Y., Peng, C.W., Li, Y.A., Xiao, B., 1985. The Sinian System on Aksu-Wushi Region, Xinjiang, China. Urumqi, pp. 1-184 (in Chinese with English abstract).

Gao, Z., Zhu, C., 1984. Precambrian Geology in Xinjiang, China. Urumqi, pp. 1151 (in Chinese with English abstract).

Gibson, G.M., Maidment, D.W. and Haren, R., 1996. Re-evaluating the structure of Broken Hill. Aust. Geol. Surv. Org. Res. Newslett. 25, pp. 1-3.

Gibson, G.M., Maidment, D.W., Haren, R., 1997. Willyama Supergroup, Broken Hill, Australia: a 1600 Ma granulite terrane situated along the Neoproterozoic margin of Gondwana following continental rifting and the breakup of rodinia. In: Bradshaw, J.D., Weaver, S.D. (Eds.), Terrane Dynamics 97, Abstracts of the International Conference on Terrane Geology. Christchurch, NZ, pp. 71-74.

Grey, K. and Corkeron, M., 1998. Late Neoproterozoic stromatolites in glacigenic succesions of the Kimberley region, Western Australia: evidence for a younger Marinoan glaciation. Precambrian Res. 92, pp. 65-87. 
Hoffman, P.F., 1991. Did the breakup of Laurentia turn Gondwanaland insideout?. Science 252, pp. 1409-1412.

Karlstrom, K.E., William, M.L., McLelland, J., Geisman, J.W. and Ahall, K.I., 1999. Refining Rodinia: geological evidence for the Australia-western U.S. connection in the Paleoproterozoic. GAS Today 9, pp. 1-7.

Kirschvink, J.L., 1980. The least squares line and the analysis of paleoamgnetic data. Geophys. J. R. Astron. Soc. 62, pp. 699-718.

Li, X.H., Li, Z.X., Ge, W., Zhou, H., Li, W., Liu, Y. and Wingate, M.T.D., 2003. Neoproterozoic granitoids in South China: crustal melting above a mantle plume at ca. 825 Ma?. Precambrian Res. 122, pp. 45-83.

Li, Z.X., 2000. New paleomagnetic results from the "cap dolomite" of the Neoproterozoic Walsh Tillite, northwestern Australia. Precambrian Res. 100, pp. 359-370

Li, Z.X., Li, X.H., Kinny, P.D. and Wang, J., 1999. The breakup of Rodinia: did it start with a mantle plume beneath South China? . Earth Planet Sci. Lett. 173, pp. 171-181

Li, Z.X., Li, X.H., Kinny, P.D., Wang, J., Zhang, S. and Zhou, H., 2003. Geochronology of Neoproterozoic syn-rift magmatism in the Yangtze Craton, South China and correlations with other continents: evidence for a mantle superplume that broke up Rodinia. Precambian Res. 122, pp. 85-109

Li, Z.X. and Powell, C.M., 2001. An outline of the palaeogeographic evolution of the Australasian region since the beginning of the Neoproterozoic. Earth Sci. Rev. 53, pp. 237-277.

Li, Z.X., Zhang, L. and Powell, C.M., 1995. South China in Rodinia: part of the missing link between Australia-East Antarctica and Laurentia?. Geology 23, pp. 407-410.

Li, Z.X., Zhang, L. and Powell, C.M., 1996. Position of the East Asian cratons in the Proterozoic supercontinent Rodinia. Aust. J. Earth Sci. 43, pp. 593-604.

Ling, W., Gao, S., Zhang, B., Li, H., Liu, Y. and Cheng, J., 2003. Neoproterozoic tectonic evolution of the northwestern Yangtze craton, South China: implications for amalgamation and break-up of the Rodinia Supercontinent. Precambian Res. 122, pp. 111-140.

Liou, J.G., Graham, S.A., Maruyama, S. and Zhang, R.Y., 1996. Characteristics and tectonic significance of the late Proterozoic Aksu blueschists and diabasic dikes northwest Xinjiang, China. Int. Geol. Rev. 38, pp. 228-244. 
Liou, J.G., Graham, S.A., Mayuyama, S., Wang, X., Xiao, X., Carroll, A.R., Chu, J., Feng, Y., Hendrix, M.S., Liang, Y.H., McKnight, C.L., Tang, Y., Wang, Z.X., Zhao, M. and Zhu, B., 1989. Proterozoic blueschist belt in western China: best documented Precambrian blueschists in the world. Geology 17, pp. 11271131.

McFadden, P.L. and McElhinny, M.W., 1990. Classification of the reversal test in paleomagnetism. Geophys. J. Int. 103, pp. 725-729.

Moores, E.M., 1991. Southwest US-East Antarctic (SWEAT) connection: a hypothesis. Geology 19, pp. 425-428

Nakajima, T., Maruyama, S., Uchiumi, S., Liou, J.G., Wang, X., Xiao, X. and Graham, S.A., 1990. Evidence for late Proterozoic subduction from 700-My-old blueschists in China. Nature 346, pp. 263-265.

Park, J.K., Buchan, K.L. and Harlan, S.S., 1995. A proposed giant radiating dyke swarm fragmented by the separation of Laurentia and Australia based on paleomagnetism of ca. 780 Mamafic intrusions in western North America. Earth Planet Sci. Lett. 132, pp. 129-139.

Pidgeon, R.T., Smith, C.B., Fanning, C.M., 1989. Kimberlite and lamproite emplacement ages in Western Australia. In: Ross, J., et al. (Eds.), Kimberlites and Related Rocks Volume 1: Their Composition, Occurrence, Origin and Emplacement. Geol. Soc. Aust. Spec. Pub. Carlton, pp. 382-391.

Plumb, K.A., 1996. Revised correlation of Neoproterozoic glacial successions from the Kimberley region, northwestern Australia. Abstr. Geol. Soc. Aust. 41, 344.

Powell, C.M. and Pisarevsky, 2002. Late Neoproterozoic assembly of East Gondwana. Geology 30, pp. 3-6.

Spencer, K.J. and Lindsley, D.H., 1981. A solution model for coexisting irotitanium oxides. Am. Mineral. 66, pp. 1189-1201.

Veevers, J.J., Walter, M.R. and Scheibner, E., 1997. Neoproterozoic tectonics of Australia-Antarctica and Laurentia and the $560 \mathrm{Ma}$ birth of the Pacific ocean reflect the 400 Ma Pangean supercycle. J. Geol. 105, pp. 225-242.

Wingate, M.T.D., Campbell, I.H., Compston, W. and Gibson, G.M., 1998. Ion microprobe U-Pb ages for Neoproterozoic basaltic magmatism in southcentral Australia and implications for the breakup of Rodinia. Precambrian Res. 87, pp. 135-159.

Wingate, M.T.D. and Giddings, J.W., 2000. Age and paleomagnetism of the Mundine Well dyke swarm, Western Australia: implications for an AustraliaLaurentia connection at 755 Ma. Precambrian Res. 100, pp. 335-357. 
Zhang, L.F., Jiang, W.B., Wei, C.J., Dong, S.B., 1999. Discovery of dolerite from the Aksu Precambrian blueschist terrane and its geological significance. Sci. China 42, 233-239.

Zhao, J.X., Malcolm, M.T. and Korsch, R.J., 1994. Characterisation of a plumerelated $\sim 800$ Ma magmatism event and its implication for basin formation in central-southern Australia. Earth Planet Sci. Lett. 121, pp. 349-367.

Zhao, J.X. and McCulloch, M.T., 1993. Sm-Nd mineral isochron ages of Late proterozoic dyke swarm in Australia: evidence for two distinct events of mafic magmatism and crustal extension. Chem. Geol. 109, pp. 341-354.

Zijderveld, J.D.A., 1967. Demagnetization of rocks: analysis of results. In: Collision, D.W., Creer, K.M., Runcorn, S.K. (Eds.), Methods in Paleomagnetism, pp. 254-286. 